\author{
NBER WORKING PAPER SERIES \\ ON \\ HISTORICAL FACTORS IN LONG RUN GROWTH
}

\title{
THE PROPERTY TAX AS A COORDINATING DEVICE: FINANCING INDIANA'S MAMMOTH INTERNAL IMPROVEMENT SYSTEM, 1835 TO 1842
}

\author{
John Joseph Wallis \\ Historical Paper 136 \\ NATIONAL BUREAU OF ECONOMIC RESEARCH \\ 1050 Massachusetts Avenue \\ Cambridge, MA 02138 \\ November 2001
}

I would like to acknowledge the financial support of the Lincoln Institute for Land Policy and of the National Science Foundation, and the research assistance of Randy Moore and John Allison. The views expressed herein are those of the author and not necessarily those of the National Bureau of Economic Research.

(C) 2001 by John Joseph Wallis. All rights reserved. Short sections of text, not to exceed two paragraphs, may be quoted without explicit permission provided that full credit, including (C) notice, is given to the source. 
The Property Tax as a Coordinating Device:

Financing Indiana's Mammoth Internal Improvement System, 1835 to 1842

John Joseph Wallis

NBER Historical Paper No. 136

November 2001

JEL No. N0, N4, N7

Development of the American Economy

\section{ABSTRACT}

The state of Indiana set out to build a Mammoth system of canals, railroads, and turnpikes in 1836, after a decade of intense debate in which sectional rivalries prevented any state action. This paper investigates the role played by the adoption of an ad valorem property tax in ameliorating the sectional rivalries and coordinating the costs of financing the transportation system with the taxes levied to finance it. It also traces the rise and fall of land values in the state between 1835 and 1842 , estimating the effect of internal improvement projects on land values.

John Joseph Wallis

Department of Economics

University of Maryland

College Park, MD 20742

and NBER

wallis@econ.umd.edu 
At the end of the War of 1812, America possessed a seemingly inexhaustible amount of land available for settlement in the west. The full potential of western land could only be realized by building a transportation network linking the fertile Ohio and Mississippi valleys with the rapidly developing economies of the eastern seaboard. Sectional rivalries repeatedly frustrated federal government efforts to build a national system of "internal improvements."1 With few exceptions, Congress was unable to forge an agreement between sections of the country on where improvements should go and how they would be paid for. ${ }^{2}$ Crossing the Appalachian barrier was left to the states. New York's bold and enterprising construction of the Erie Canal, begun in 1817, inaugurated the state canal era, followed by Ohio, Pennsylvania, and Maryland in the 1820s. Indiana, Illinois, and Michigan began work on canals and railroads in the mid 1830s, even as New York and Ohio expanded their canal systems and Massachusetts and Georgia were working on railroads.

It might appear that states, with their smaller land areas and relatively more homogenous populations, were able to avoid the geographic conflicts that plagued the national government. Such was not the case. Americans struggled to implement a vision of democracy in which the government played a positive role in promoting economic development, at the same time that the government did not unduly burden one group to benefit another. Canals were, by nature, geographically specific enterprises. Construction of a canal unavoidably privileged some geographic areas at the expense of others. One apparent solution was to build canals (or railroads) everywhere at once, a solution often credited for overburdening transportation systems in Pennsylvania, Indiana, and Illinois. Logrolling, however, was only an apparent solution. States could not build canals to every county. Some way had to be found to reconcile and 
coordinate the disparate interest of taxpayers and the promoters and supporters of internal improvements. $^{3}$

Conditions were unique in every state, but in the central tier of states through which the major east/west transportation routes would ultimately run - New York, Ohio, and Indiana states reconciled geographic competition over canals in the same way. Each state altered their existing property taxes to more carefully bring the costs of financing internal improvements into line with the geographic distribution of benefits. In New York, in 1817, the state created a special "canal tax" to be levied on counties on the canal if it became necessary to raise additional funds to service state bonds. In Ohio in 1826 and Indiana in 1836, new ad valorem property taxes on land and other personal property were created to shift the burden of state taxation from agricultural land assessed on a per acre basis to a more equitable base of farm lands, town lands, and personal property. Miller's Enterprise of a Free People and Scheiber's Ohio Canal Era show how important tax changes were in New York and Ohio. Indiana's story has yet to be told. Close examination of the Indiana history reveals a hidden treasure. Not leaving the geographic distribution of taxes to chance, in 1835 Indiana commissioned the state Auditor to prepare a report detailing how the proposed ad valorem property tax would effect each county in the state. That report forms the basis for a statistical inquiry into the effects of internal improvement construction on land values throughout Indiana.

In 1830, much of Indiana was wilderness: Indians still held claim to the north west quarter of the state. Except for long settled southern counties along the Ohio river, a natural highway to the Mississippi and eastern markets, Hoosiers were far removed from the transportation necessary to bring their agricultural goods to market. Without better 
transportation, Indiana land was worth little more than the $\$ 1.25$ an acre it brought at public auction, a lack acutely appreciated by the farming land speculators that made up the electorate. After a decade of debate, in 1836 the Indiana legislature authorized the commissioners of the state's Board of Internal Improvement to borrow up to $\$ 10$ million dollars, at an interest rate of no higher than 5 percent, to survey and construct a network of canals, roads, and railroads spanning the state. ${ }^{4}$ In 1836 , Indiana had a population of less than a million people and annual tax revenues of about $\$ 50,000$. Financial difficulties (not of their own making) forced the state to suspend construction on canals and railroads in 1839. By 1841, the state was in default on over $\$ 12,000,000$ in state debts, none of the canals or railroads were completed, and Indiana and the nation were in the grip of the deepest depression of the $19^{\text {th }}$ century. ${ }^{5}$

This essay is devoted to Indiana. ${ }^{6}$ The major obstacle to internal improvements in Indiana was sectional, just as it was in the nation. Clearing up a few misunderstandings in the historical record makes clear how the shift to ad valorem taxation placated section rivalries and made the enactment of the "Mammoth" system of internal improvements possible in 1836. The majority of Indiana counties expected to pay a lower share of state taxes under the ad valorem system than under the old per acre land tax. Towns, with their urban land and larger holdings of personal property, bore significantly higher tax burdens under the ad valorem system. It was, of course, those very same towns that expected to gain the lion's share of gains from the construction of canals and railroads. The discussion also reveals why Indiana thought it could finance the Mammoth system: the prospect of substantial additions to its property tax base after $1841 .^{7}$

The sectional compromise reached in 1836 anticipated that internal improvement counties would pay higher taxes, requiring land values rise more rapidly in counties with canals or 
railroads. Indiana land values are tracked through the boom and bust cycle using Auditor's Reports for 1835,1837 , and 1842 . Internal improvement counties did realize the largest gains in land values between 1835 and 1837 . The terms of the bargain reached in 1836 were fulfilled. Unfortunately, internal improvement counties also bore the brunt of the economic collapse after 1839 , and we are able to estimate how much of the decline in Indiana land values after 1839 was caused by cessation of construction on the state system.

\section{Geography and History.}

When Indiana entered the Union in 1816, its population was concentrated in a narrow band of counties along the Ohio river. ${ }^{8}$ Indians controlled roughly two-thirds of the state until the "New Purchase" of 1818. In a treaty signed at St. Mary's Ohio, the Delaware, Weas, Kickapoos, Pottawattomie, and Miami tribes agreed to cede territory and withdraw to the north side of the Wabash river. The tribes continued to hold this land until another round of cessions and treaties in the late 1820 s and early 1830 s. The Wabash river rises in northeastern Indiana and empties into the Ohio river in the southwest corner of the state (Figure 1). Moving upstream from the Ohio, the lower reaches of the river form the southern portion of the boundary between Indiana and Illinois. Below Terre Haute, the river enters completely into Indiana, where the river runs north to Lafayette. From there it bends to the east, traversing the state and passing about 30 miles southwest of Fort Wayne. A short portage connects the Wabash with the Maumee river near Fort Wayne. The Maumee runs northeast, through the northwest corner of Ohio and into Lake Erie. The Wabash held out the hope of an all water route from the Ohio river to Lake Erie, offering cheap and reliable transportation to much of central Indiana. The Wabash was the highway along 
which settlers moved into the western and then northern portions of the state, and it marked the northwestern boundary of settlement until the treaty reached at Tippecanoe in October of 1832 opened the northern portion of the state to settlement. The value of millions of acres of farm land opened for settlement in northern Indiana in the late 1820s and early 1830s depended directly on opening the Wabash and Erie route.

While the Wabash defined the geography of northern Indiana, its also defined a fault line for a political battle within the state. The southeastern river counties of Dearborn, Switzerland, Jefferson, Clark and Floyd already had access to the Ohio river above the Falls of the Ohio (on the river at Jeffersonville, across from Louisville, KY), and via the Ohio canals begun in 1826, a water route to Lake Erie. The tier of counties to the immediate north of Dearborn (see Figure 1) Franklin, Fayette, Union, and Wayne were located on the Whitewater river, and were a canal to be built on the Whitewater those counties, plus the three counties immediately to the west, Rush, Decatur, and Ripley, would also have access to a reliable water route. In 1834, these twelve counties contained 29 percent of the voters in the state. This third of the electorate stood to gain nothing from developing the Wabash and Erie route, which would only serve the western and northern portions of the state. ${ }^{9}$

The cession of Indian lands to the federal government brought national interests into play as well. The federal government was interested in promoting land sales, and with the active support of President Adams, in 1827 Congress made a grant of land to the state of Indiana to assist in the construction of the Wabash \& Erie canal east from the mouth of the Tippecanoe river (near Lafayette), across Ohio to Lake Erie. This was the first federal land grant to employ the policy of granting alternating sections, one-half of five sections on either side of the canal, in a 
strip 5 miles wide and 160 miles long, a total grant of 527,000 acres. In return, the state was obligated to begin construction within five years and complete the canal within twenty years. The grant was a triumph for the Indiana Congressional delegation, but problematic back home:

Most people lived on the lower reaches of the Wabash and Whitewater valleys, a hundred miles or more from the site of this canal. Nor was the capital city, Indianapolis (still a muddy, pioneers camp to which the government had moved just two years before), much closer. More urgent projects - canals around the falls of the Ohio and up the Whitewater River, clearing the lower Wabash, and building innumerable highways - still waited for public expenditures. Many saw the Wabash \& Erie Canal as the speculative hobby of Fort Wayne Indian agent John Tipton (who stood to gain a fortune in Indian lands). Few people relished the idea of encumbering the state's energy and scarce resources with a project in the northern wilderness, while the vast majority of voters and taxpayers stayed quite literally stuck in the mud of southern Indiana's roads and rivers. ${ }^{10}$

The grant, however, was too attractive to pass up, and in the summer of 1832 the state created a Board of Canal Fund Commissioners and began construction of the Wabash \& Erie. Indiana was in the canal business, if only in a small way.

The early years of the 1830 s brought renewed prosperity to Indiana and the entire western region of the country. Table 1 provides some basic information for the years 1834 to 1843 : national land sales in thousands of acres, public land sales in Indiana in thousands of acres, acres of land subject to taxation, the value of land and improvements, the value of town lots, average per acre value of land including and excluding town lots, and total tax revenues from all source collected in each fiscal year. The table shows the peak of land sales in 1836, the peak of land values in 1837, and the rapid decline in land values after $1839 .{ }^{11}$ Note one unusual feature of Table 1: the lag between public land sales and acres of land subject to taxation. Every state admitted to the Union from Ohio in 1803 to Missouri in 1821 was prohibited from levying taxes on land for five years from the date of sale to a private individual. The lag is pivotal in 
understanding Indiana's optimism about its fiscal future in 1836. The 1834 the state levied taxes on 4,651,000 acres of land. In 1835 and 1836 alone, public land sales in Indiana totaled $4,823,000$ acres. The state expected its property tax base to double in acreage in 1840 and 1841 , an increase augmented by the new ad valorem property tax ability to tax rising land values. The state's expectations were realized through 1839. Although public land sales in 1835 and 1836 were extraordinary by any measure, 1836 was not the end of the boom in Indiana. ${ }^{12}$ Land sales fell back from their 1836 peak in 1837 and 1838, but stayed high by historical standards into 1839. Land values stayed high through 1839 as well.

Once construction began on the Wabash \& Erie canal in 1832, pressure mounted to do something for other parts of the state. Economic conditions were improving and land sales were booming. Southeastern Indiana made a strong case for building a canal along the Whitewater; southwestern Indiana demanded that the lower Wabash be cleared or a canal constructed; and central Indiana, rapidly growing and the home of the new capital, argued for a cross cut canal or railroad to connect the widespread regions of the state. The state's resources, however, were limited. The fiscal potential created by opening northern lands and the boom in land sales throughout the state could not be realized immediately because of the tax moratorium. Early public sales of Wabash \& Erie canal lands had been disappointing. Governor Noah Noble, elected in 1831 on an anti-internal improvement platform, switched his position and became the leading proponent of transportation investment. ${ }^{13}$ Noble eased some of the opposition concerns to higher taxation when, in his annual message to the legislature in December 1833, he proposed that the canal system might be carried out with borrowed funds. ${ }^{14}$ With Noble's support and urging, passage of some internal improvement system seemed inevitable in Indiana. 
Only the most optimistic supporters suggested that the canals would immediately produce revenues capable of servicing the proposed debt (plans did not anticipate completion of the system until well into the 1840s), some taxes would have to be raised to pay interest. Internal improvement supporters faced two intertwined challenges: deciding which parts of the state would get projects and how the tax burden would be distributed across the population. Indiana legislatures met during the winter, typically from December to February. The session that ended in 1834 failed to produce a canal bill. The 1835 session spent a great deal of time arguing over proposed canal and railroad routes. The Indiana Democrat reported on January 20, 1835 that "We have never witnessed, in our ten years experience of legislative matters, so much interest manifested on any other question." ${ }^{15}$ In the end, however, intense sectional disputes stood in the way of compromise. As Nathan Palmer wrote to Senator John Tipton "A decided majority appeared to be in favor of entering into a general sistem [sic], but the rock upon which they split, was the details of the bill. -- Such was the conflicting interest that it seemed impossible to agree, $\&$ finally the matter fell, to be recusitated [sic] at the next session.. ${ }^{16}$ Instead of authorizing construction, the legislature passed a canal bill on February 6, 1835, requiring the Canal Fund Commissioners to study the feasibility of a number of canals, roads, and railroads.

In was not until January 27, 1836, that Indiana passed the Mammoth Internal Improvement bill. The bill created a Board of Internal Improvement and authorized it to borrow up to $\$ 10$ million, secured by the good faith and credit of the state. The Board was to continue construction of the Wabash \& Erie and extend its western terminus to Terre Haute; to begin clearing the lower Wabash; to begin construction of the Whitewater Canal; to begin construction of a Central Canal to connect the Wabash \& Erie at Fort Wayne with the Whitewater canal via Indianapolis, and to 
extend south to Evansville on the Ohio river; to begin building the Madison railroad connecting Indianapolis with Madison in Jefferson county; to begin several new roads; and to begin surveying routes for proposed roads, canals, and railroads. The main projects and their routes are shown in Figure 1.

II. Ad Valorem taxation and the Mammoth Bill.

Indiana historians have understood that passage of the Mammoth bill was somehow connected to changes in the structure of property taxation, but the link has never been made explicit. Occasionally historians have ignored the new tax system altogether. ${ }^{17}$ The change to ad valorem property tax changes is usually dated 1835 , while the Mammoth bill is always dated 1836, giving the impression that the two changes occurred at least a year apart in time. In the 1840s, Indiana politicians blamed the collapse of the system on the fact that projects had been started in so many parts of the state in order to placate sectional rivalries. ${ }^{18}$ It was forgotten that changes to the property tax were just as important in working out the regional compromise as starting projects all over the state. Indeed, legislators required that the compromise over taxation be made explicit before the Mammoth bill could go forward.

Prior to 1835, Indiana relied on two revenue sources: a poll tax and a land tax. Land was classified into one of three categories -- first, second, and third rate -- and was taxed by the acre. The rates in force since 1831 levied a tax of "eighty cents on each hundred acres of first-rate land, sixty cents on each hundred acres of second-rate land, and forty cents on each hundred acre of third-rate land." ${ }^{19}$ Polls, "each male inhabitant between twenty-one and sixty years of age, who is sane and not a pauper," were taxed at thirty-seven and a half cents per person. In fiscal 1834, the 
state levied $\$ 28,362$ in poll taxes and $\$ 25,807$ in land taxes. As Indiana legislators contemplated an internal improvement system in the winter of $1834 / 35$, they also considered an ad valorem property tax. It was generally believed that the proposed changes in the property tax could have regional implications. Land owners in older, southern agricultural regions were sure that taxing land by value would disproportionately raise their tax burden. ${ }^{20}$

In his message to the legislature on December 2, 1834, Noble recommended that Indiana consider changing its "revenue laws to insure greater accuracy and uniformity, as well as economy, in assessing and rating lands for taxation.."21 An act to "provide for an equitable mode of levying the taxes of this state" was approved February 7, 1835. The act charged the Auditor of the state and the clerks of each county with appointing assessors to "take a list of all the taxable inhabitants of his township, and make an assessment of all the property therein made subject to taxation by this act, and for that purpose he shall call on each person resident in his township, and request of such person a list of all his property liable to taxation as aforesaid in said township;,..,22 The act, however, did not levy any taxes. It mandated that information be collected on the value of land and personal property in order to make an informed decision about changing the revenue law. Every taxable inhabitant heard about the proposed law, as they were each to be visited by the assessor in their township. The proposed tax was levied on personal property as well as land, but over two-thirds of the tax would fall on land.

The revenue law was intimately connected to the internal improvement bill considered at the same session. The Indiana Journal, January 5, 1835, reported on an amendment proposed by Mr. Clark to the internal improvement bill then under consideration. The amendment would have put off construction on any projects until further study was made and: "Also to inquire if it not be 
necessary that an ad valorem system of taxation be adopted by the state before entering upon any system of internal improvement, and providing that lands in the vicinity of the contemplated works shall be rated with a reference to the increased value they will acquire, and thereby make the burthen of constructing works of improvement bear a proportion corresponding with the benefits received." Although Clark's amendment was rejected, the legislature ultimately enacted the amendment's substance in the revenue bill of February 7, 1835, which required the Auditor to prepare a report on the effects of an ad valorem tax, and in the internal improvement bill passed on February 6, 1835, which required the commissioners of the canal fund to prepare a report on the canal and railroad projects authorized a year later in the Mammoth bill. The Indiana Democrat, February 27, 1835, understood the connection between the tax law and the internal improvement bill. "This law was considered by many as an entering wedge of the general system of [internal] improvement contemplated at the next session."${ }^{, 23}$

Because the structure of the new property tax was contained in the 1835 bill, ad valorem taxation in Indiana is typically dated from 1835 , even though ad valorem taxation was not authorized until the revenue bill of February 8, 1836 levied the first ad valorem tax. Internal improvements in Indiana date from the Mammoth bill of January 27, 1836. Internal improvements and ad valorem taxation were intimately connected, for the reasons that Clark laid out in his amendment: the equalizing effect of land taxation on the distribution of tax burdens.

III. Ad valorem taxation compared to per acre taxation.

How did the proposed ad valorem tax compare to the old per acre tax? In his Governor's message of December 8, 1835, Noble reported: 
The law of last session, providing for a change in our revenue system, does not require the clerks of the several counties to report the returns of the assessors to the Auditor of State before the first day of December, consequently I am not able to present you with a view of the result of the valuations. From the best information I can obtain, however, it is believed that the disparity anticipated in the value of real estate in the old and new districts of the state, does not exist. If, upon a comparison of all the returns, this opinion shall found to be correct, there can be but little reason to question the policy or justice of a change [to ad valorem taxation]. ${ }^{24}$

We can compare the returns of the State Auditor for 1834 and 1835 to ascertain the amount of property tax paid by each county under both forms of taxation. The results were surprising (they are reported by county in appendix Table A1). In both years the state expected to receive roughly $\$ 25,000$ from the property tax on land, so we can compare directly the amount of tax paid by each county. Of the 55 counties for which complete information is available in both years, 39 paid less tax under the ad valorem scheme than the old system. ${ }^{25}$ Ad valorem taxes were less than 80 percent of per acre taxes in 28 counties, while in only 12 counties were ad valorem taxes more than 120 percent of per acre taxes. The figures in the table and in the analysis, focus on the value of land and improvements, excluding town lots and personal property. ${ }^{26}$

Noble noted the reason why so many counties paid lower taxes: "No good and satisfactory reason can be assigned why capital invested in town property, bank stock, merchandise or money at interest, should not be subject to the same rate of taxation as an equal amount invested in land." 27 The numerical majority of land owners in Indiana were farmers and the per acre tax fell largely on their land. Ad valorem taxation enabled to the state to tax the value of town lands and other personal property, and shift some of the tax burden away from agricultural land. Agricultural land in the older southern counties did not experience higher taxes as a result of the shift to ad valorem taxation (see below) and southern opposition to the canal bill was substantially 
muted as a result. Indiana was not a heavily urbanized state in 1835 , and the small number of town residents bore a larger share of the tax burden under the new tax system. The adoption of the ad valorem tax, however, was not the result of tyranny of the majority, other forces were also at work.

Indiana towns were located at breaks in the transportation network. When the state planned the system of internal improvements, it chose routes that followed existing rivers (a necessity for canals) and ran between existing population centers. To do otherwise made no sense. Although farmers along canal and railroad routes expected to benefit from lower transportation costs, the big winners from internal improvements, and therefore the most vocal promoters, were the mercantile interests in the towns located in the interstices of the system. Appendix Table A1 also includes the share of all land value in the county in town lots in 1835 , and a variable "terminus" indicating whether two or more transportation lines (actual or proposed) intersected within the county. The table is sorted by the ratio of taxes paid under the per acre tax to taxes paid under the ad valorem tax. Counties whose taxes rose under the ad valorem system were much more likely to have a high share of town property in their total assessed land value, and they were more likely to be terminus counties.

Table 2 presents the results of bivariate regressions where the dependent variable is the ratio of ad valorem taxes proposed in 1835 to per acre taxes levied in 1834 . The tax ratio is regressed on a dummy variable for "internal improvement" counties (all counties including a canal, railroad, or turnpike proposed in the Mammoth bill), a dummy for "terminus" counties (all counties including an intersection of two transportation routes, including the Ohio River), "town lands" (the value of town lands as a share of total land value in each county), and "latitude" (the 
latitude of the central point of each county). Standard errors are reported below each coefficient estimate. $^{28}$

The results clearly indicate counties that ultimately received a canal or railroad paid higher taxes. On average, ad valorem taxes in internal improvement counties were 33 percent higher than in non-internal improvement counties. Terminus counties, including all of Indiana's larger towns, paid ad valorem taxes that were 73 percent higher than non-terminus counties. This result is confirmed by the estimates for town lots. A one percentage point increase in the share of town land in the total land value in a county of increased that county's ad valorem taxes by 2.5 percentage points. Finally, the estimates for latitude address directly the concerns of southern counties, who felt they would pay higher taxes under the ad valorem scheme. Instead, northern counties paid slightly higher ad valorem taxes than southern counties relative to the per acre tax.

The regression estimates only emphasize what the eye sees in the raw data. The dozen counties that paid substantially higher ad valorem taxes were the primary beneficiaries of internal improvement investment (a point substantiated in the next section). Had the shift in revenue structure not been tied to the internal improvement program, the towns would have adamantly opposed the change. Towns stood to gain the most from canals and railroads, and they were quite willing to exchange higher taxes for the benefits they saw just over the horizon.

IV. Internal Improvement investment and per acre land values.

Indiana approved the Mammoth Bill and implemented the ad valorem property tax in the winter of 1836. Construction on canals and railroads began in the summer and counties began collecting the property tax. Property taxes collected in 1836 were based on the 1835 assessments 
and another round of assessments was made in 1837. By comparing the assessed value of land in 1835 and 1837, we can measure the impact of internal improvement construction on land values. If the intentions of the legislature were realized, counties located along canal and railroad routes should have experienced a larger increase in property values than counties off the routes. In this section the effects of internal improvements on per acre land values are estimated. In the next section the per acre effects are translated into aggregate effects.

As already discussed, when the state began construction in 1836, it expected its property tax base to double in size by 1841 simply through the addition of taxable acreage, augmented by any rise in land values captured by the ad valorem property tax. The expectations were realized through the summer of 1839. As long as construction continued, land values stayed high. The state was able to borrow money in national and international credit markets, through the services of several investment banks, the most important being the Morris Canal and Bank company of New Jersey. In retrospect, it was unfortunate that the state chose to sell bonds on credit to the Morris Bank. The bank agreed to take several million in state bonds and repay the state in installments. The state assumed liability for the bonds immediately, but was not paid for the bonds for several years. In the summer of 1839 , the Morris Bank defaulted on over $\$ 2,000,000$ of its obligation to Indiana. The state relied on the Morris Bank installments to meet interest payments and to pay contractors. Construction on state projects was halted in August of 1839. With the end of construction land values began to plummet. The state struggled to meet its interest payments in 1839 and 1840. While it raised tax rates in an attempt to generate more revenue, property values fell. By 1842 , average land values were half of their 1837 values. The state was bankrupt and suspended interest payments on its debts in $1841 .{ }^{29}$ 
Our primary concern is to determine whether counties with canals realized higher land values. In 1835 and 1836, when the Indiana legislature authorized the Mammoth bill, land values were increasing throughout Indiana and the country. This general rise in land values should not be attributed to the Mammoth bill. Likewise, after 1839, when construction on the Indiana system halted and land values began to plummet, not all of the decline in land values should be attributed to the cessation of internal improvement construction.

Table 3 presents some simple, but persuasive difference in difference results. Between 1835 and 1837 land values in Indiana rose sharply, by an average of $\$ 3.90$ an acre, by $\$ 4.55$ an acre in internal improvement counties, and by $\$ 2.74$ in non-internal improvement counties, ${ }^{30} \mathrm{a}$ difference of $\$ 1.81$ an acre. This is an estimate of how much canals and railroads raised land values, after accounting for the general rise in land values. The $\$ 1.81$ figure underestimates the effect of internal improvements on land values: the location of planned canals was public knowledge and land values had already risen in anticipation of construction when property assessments were made in 1835. Since construction on canals and railroads came to halt in the summer of 1839, a second difference in difference estimate comparing 1837 and 1842 gives us another way to measure the benefits of building canals and railroads, this time by measuring how much land values fell when it became clear that the projects would not be completed. ${ }^{31}$ The second column of the table shows that land values fell by an average of $\$ 4.21$ an acre statewide between 1837 and 1842 . The decline was $\$ 5.49$ an acre in internal improvement counties and $\$ 2.80$ an acre in non-improvement counties, a difference of $\$ 2.69$ an acre. The average value of raw land (excluding improvements) was only $\$ 3.85$ an acre in 1842 . Land owners expected substantial benefits from canals and railroads, benefits that were capitalized into land values. The 
effects were very large, and contributed substantially to the rise in land value up to 1837 and the collapse of land values after 1839.

The second and third panel of the table calculate difference in difference estimates for two alternative groups of counties. "Terminus" counties contain an intersection between major canals, railroads, turnpikes, or rivers. The increase in property values between 1835 and 1837 was concentrated in the terminus counties. Appendix Table A2 gives the change in property value per acre between 1835 and 1837 , between 1837 and 1842, and indicates whether a county is a terminus county. Between 1835 and 1837 , land in terminus counties rose in value by $\$ 8.29$ an acre and by only $\$ 2.93$ an acre in non-terminus counties, a difference of $\$ 5.36$ an acre. Likewise, land value per acre fell by $\$ 9.06$ an acre in terminus counties and by $\$ 3.11$ an acre in nonterminus counties between 1837 and 1842, a difference of $\$ 5.95$ an acre. Land markets were active throughout the state, average land prices doubled in the typical county, but terminus counties were the center of the major land speculations. The towns were big canal promoters, agreed to pay higher taxes, and reaped the benefits of higher land values.

The third panel of the table separates counties by the ratio of per acre taxes paid in 1834 to ad valorem taxes under the 1835 assessment (again, comparing $\$ 25,000$ of land taxes in both years and excluding town lots and personal property in 1835). The comparison is limited to counties with a ratio of less than .8 or more than $1.2 .^{32}$ Counties that paid higher taxes under $a d$ valorem experienced a rise in property values of $\$ 4.91$ between 1835 and 1837 , while counties with lower taxes under ad valorem experienced only a \$2.99 rise in per acre value, a difference of $\$ 1.92$ an acre. Between 1837 and 1842, value per acre fell by $\$ 5.38$ in high tax counties and by only $\$ 2.14$ in low tax counties, a difference of $\$ 3.24$ an acre. These results are striking evidence 
that, ex ante, counties that expected to realize large gains in property value because of canal and railroad construction were the same counties that, ex post, not only paid higher taxes but realized greater gains in land values. However we segregate the counties, land values rose disproportionately in internal improvement counties between 1835 and 1837, and fell disproportionately between 1837 and 1842 .

The upper panel of Table 4 reports the results of bivariate regressions that duplicate the difference in difference results for internal improvement and terminus counties, and conveniently provide standard errors for the difference estimates. (Table 5 presents means and standard deviations for the variables used in the regression analysis.) The dependent variable in each regression is the change in the value of land and improvements per acre in each county between 1835 and 1837 or between 1837 and 1842 . In the regressions, the ratio of 1835 ad valorem taxes to 1834 per acre taxes is entered as a continuous variable. The lower panel of the table presents two specifications for each time period, again the dependent variable is the change in the land value per acre. When both terminus and internal improvement counties are included, terminus counties raise land values by $\$ 5.21$ an acre between 1835 and 1837 , and lower land values by \$5.44 an acre between 1837 and 1842, while internal improvement counties have much smaller effects, raising land values by $\$ .34$ an acre between 1835 and 1837, and lowering land values by $\$ 1.06$ an acre from 1837 to 1842 . The estimated effects for the terminus counties are in line with the difference estimates, and indicate that most of the action in both periods was in terminus counties. The second specification breaks up counties by the specific improvement located within their borders. Again, terminus counties have a large effect in both periods. The Fort Wayne and Michigan canal counties realize gains of $\$ 6.51$ an acre between 1835 and 1837, all of which was 
lost between 1837 and 1842 .

The Whitewater case is particularly interesting. ${ }^{33}$ The Whitewater canal, started in 1836 , was to run from Wayne County south to Dearborn County. Construction started first on the south end of the canal, and by June of 1839 the lower half of the canal had been opened from Lawrenceburg to Brookeville. Construction then stalled, and when the state was unable to complete work "the canal was sold to Henry S. Vallette, a wealthy Cincinnatian, who proceeded to complete it." Construction on the Whitewater continued until 1846 when the canal reached Hagerstown in Wayne county. Whitewater canal counties realized a gain of $\$ 3.53$ an acre between 1837 and 1842, controlling for the terminus effect (two Whitewater counties are also terminus counties). The experience of the Whitewater counties shows what happened to land values in counties where canals were completed.

For those who are interested in the determinants of the level of land values per acre, rather than changes in land values over time, Table 6 presents results from a regression of land values in individual years on dummies for internal improvement and terminus counties, as well as polls and taxable acres of land in each county. As is expected, polls (a proxy for population) exert a strong positive effect on land values and taxable acreage a strong negative effect on land values. Internal improvements counties have small positive effects on land values in each year (controlling for terminus counties, without the terminus dummy the internal improvement coefficient is larger). Terminus counties have small positive or even slightly negative effects in 1835 and 1842 , but very large positive effects on land value per acre in 1837. As in the difference estimates, land values in terminus counties are roughly $\$ 5$ an acre higher in 1837 . This effect is extremely robust to different specifications. 
V. The effect on aggregate land values

The fluctuations in land values were greatest in the town centers where transportation routes intersected. These effects are clear from the per acre estimates in Tables 4 and 6, but how did that translate into aggregate land values and, critically for the state treasury, property tax revenues? The panels of Table 7 look at aggregate land values from three perspectives. The first panel presents acres of land subject to taxation, total value of land and improvements, and value per acre for the entire state. The first three columns are for 1835,1837 , and 1842 , and the last two columns for the change between 1835 and 1837 and between 1837 and 1842. Between 1835 and 1837, land prices doubled and aggregate land value doubled as well. Between 1837 and 1842 acres subject to taxation doubled while land values fell by almost half. As a result, aggregate land value increased by only 20 percent between 1837 and 1842 . This is the key to why Indiana would default on its debts in 1841: the state knew in 1836 that the amount of land subject to taxation would double by 1841 , but when 1841 arrived the aggregate value of land had barely increased.

The second and third panels of the table perform similar calculations for the internal improvement counties and for the terminus counties. Between 1837 and 1842, the amount of land subject to taxation doubled in internal improvement and in terminus counties, but land values fell far enough in terminus counties that the aggregate value of land decreased between 1837 and 1842. The last row of the second and third panels estimates the effect of internal improvements on aggregate land values between 1835 and 1837 and between 1837 and 1842 . The effect is calculated by multiplying in the per acre change in land value attributable to internal improvements (terminus), taken from Table 3 , by the internal improvement county acreage (or 
terminus county acreage) taxed in 1842 . The 1842 acreage is appropriate for estimating the fiscal impact, since all of the land taxed in 1842 had been sold by 1837, and everyone knew that it was in the tax base for 1842 .

The prospect of internal improvements raised land values between 1835 and 1837 by somewhere between $\$ 17$ and \$22 million, while the end of internal improvement construction reduced land values by about $\$ 25$ million. Had construction on internal improvement projects not stopped in 1839, land values in Indiana would have been \$25 million higher in 1842 than they actually were, about 1/3 higher than the assessed value of $\$ 73$ million of land and improvements. At the property tax rates in place in 1841 , that $\$ 25$ million would have produced an additional $\$ 100,000$ in tax revenue, and might have allowed the state to avoid default. ${ }^{34}$

The \$25 million figure is important in another traditional sense. Estimates of the total cost of the Mammoth system ranged from \$10 to \$20 million (higher from opponents, lower from advocates), but none of the estimates was higher than $\$ 25$ million. If we take $\$ 25$ million as a reliable estimate of the benefits land owners in Indiana expected to receive from building the canals and railroads proposed in January of 1836, then the canals and railroads appear to have been good investments. That is, the present value of the benefits of building the canals and railroads exceeded the present value of the costs of building the canals and railroads.

\section{Conclusions}

This paper contributes to several strands of early $19^{\text {th }}$ century American economic history. On the technical side, it adds to the empirical studies showing the relationship between transportation investment and land values, as in recent papers by Craig, Palmquist, and Weiss and 
by Coffman and Gregson. Fogel used the change in land values after railroads were built as a rough estimate of social saving in Railroads and American Economic Growth. What distinguishes the Indiana experience is the large fluctuations in land values within a very short period of time and the concentration of price changes in the terminus counties. The terminus effect is not an "urbanization" effect. These counties did not become more urbanized between 1835 and 1837 and then less urbanized between 1837 and 1842 . The terminus result suggests that very substantial gains in land values may be overlooked if our primary focus is rural agricultural land. What is commonly attributed to urbanization may truly be capturing some of the benefits of transportation investment.

The history of the state default crisis of the early 1840 s treats Indiana and its fellow western defaulters as hopelessly naive, if not truly delusional, investors with wildy unrealistic expectations about the prospects that their canals and railroads would pay for themselves. In order to appreciate the situation in Indiana and throughout the country in the mid-1830s it is necessary to look at a wider range of states than are encompassed here, a task addressed in other papers. But we can understand why Indiana thought it could handle a $\$ 10$ million internal improvement investment program in 1836. Had land values remained at their 1837 levels through 1842, the state never would have defaulted on its debts.

What role did Indiana play in the Crisis of 1839? Suspending construction on the Indiana canals in 1839 sharply reduced the value of land in Indiana from 1839 to 1842 . Indiana was the first state hit by the defalcation of the banks in 1839 and the first state to halt construction (Illinois and Michigan would follow shortly). Whether events in Indiana precipitated the Crisis of 1839 (which broke in October) or whether Indiana was caught in the general contagion that spread 
throughout the economy that year is a fascinating question, again, one beyond the scope of this paper. Now, however, we can gauge the effect of internal improvement investments on land values, and thereby assess their effect on the land boom and the land bust. The loss of $\$ 25$ million of land value in 14 terminus counties between 1837 and 1842 suggests that internal improvement projects had a very large effect on the land boom before 1837 and the collapse of the market after 1839.

An appreciation of the ingenious ways in which American governments pursued the sometimes conflicting goals of promoting economic development while nurturing democratic political institutions is the focus of this paper. Indiana wanted canals and railroads for very good economic reasons. The typical citizen was a land speculator, if only in a small way, and the median voter certainly wanted to raise land values by building transportation improvements. Inevitably, however, building a canal rewarded some groups at the expense of others, an outcome inconsistent with beliefs about the fairness of democratic outcomes. Indiana struggled for a decade to find a compromise between sectional interests that would enable it to go forward with a system of transportation improvements. Ultimately, the compromise was not to build canals and railroads to every county. If that had been the only constraint the Indiana legislature could have passed the Mammoth bill in 1835.

The critical compromise reallocated the burden of taxation across counties to coordinate the expected benefits of transportation expenditures with the expected costs of taxation. The Auditor's Report published in December of 1835 made comparison of tax burdens under the old per acre tax and the proposed ad valorem property easy and explicit. The majority of counties paid lower taxes under the new tax than the old tax. Southern counties who opposed statewide 
internal improvement spending paid lower taxes under the new tax than the old tax. Counties located on the intersections of major transportation routes, however, counties with towns that expected to reap the largest gains from state expenditures, paid substantially higher taxes under the new tax than the old tax. Terminus counties paid ad valorem taxes that were, on average, 73 percent higher than they paid under the per acre tax.

Indiana voters and politicians may have been naive: they certainly didn't perceive that land values would fall precipitously after 1839 , but there was nothing naive about the compromise they reached. They correctly anticipated how land values would be affected by canal and railroad construction. The average per acre value of land and improvements in 1835 was $\$ 5.41$. Between 1835 and 1837 , value per acre rose by $\$ 2.74$ in non-improvement counties, $\$ 4.55$ in improvement counties, and $\$ 8.29$ in terminus counties. Property taxes on land and improvements in terminus counties rose three times faster than in non-improvement counties. The property tax coordinated the benefits of canal construction with the taxes levied to finance canal costs, enabling opponents and supporters of Indiana's Mammoth system to reach a political compromise and launch Indiana's ill-fated era of internal improvements. 


\section{Endnotes}

1.As Larson, 2001 and 1987, and Goodrich, 1960 and 1948, explain, the federal government was unable to support a national system of canals and/or railroads before the Civil War because of concerns over national power and sectional rivalries. Larson and Goodrich are excellent histories of the internal improvement movement in the 1820s, 1830s, and 1840s, and provide a background for the Indiana experience studied in this paper.

2.What might seem to be the major exception, Congress's passage of the Bonus Bill in 1817 allocating the bonus paid by the Second Bank of the United States to a fund to support internal improvements, is the exception that proves the rule. The Bonus Bill did not specify any projects, indeed it could not have passed had it done so. Calhoun, the bill's sponsor, admitted a bill specifying projects in detail could not be passed: "The enemies to any possible system in detail and those who are opposed in principle, would unite and defeat it." Annals of Congress, $14^{\text {th }}$ Congress, $2^{\text {nd }}$ session, p. 852-58 (As quoted in Larson, p. 66). Instead, the Bonus Bill allocated money between the states on the basis of population, insuring that no major projects would be built in any state(s). See Larson's discussion of the Bonus Bill, pp. 64-67.

3.'Internal improvements" encompasses transportation improvements of all types. Railroads were just coming on the scene in the late 1820 s and early 1830 s. From the standpoint of state investment, canals and railroads were very close substitutes. "Canals" are often used in the text where "canals and railroads" would be equally appropriate.

4."An Act to provide for a general system of Internal Improvements." Indiana Laws, Chapter II, Indiana General Assembly, $20^{\text {th }}$ session, p. 5. The history of the Indiana canals is told in Fatout, Carmony, and Esarey.

5.The best source on history of state borrowing and the debt crisis is McGrane. Ratchford provides additional information. For more recent studies of the debt crisis see English, Sylla and Wallis, and Wallis, Grinath, and Sylla.

6.Peculiarities in the history and administration of the property tax in New York and Ohio make it impossible to duplicate this analysis in those states. For more than a decade from the $1820 \mathrm{~s}$ to the 1830s New York suspended its state property tax entirely, and the state stopped collecting information on assessed values and property taxes in the counties. Ohio was notorious for not reassessing land values. Once entered on the books property values would remain unchanged for years, rendering problematic variations in land values over short periods of time.

7.Wallis, Grinath, and Sylla show that Indiana could have serviced interests payments on the state debt after 1841 if land values had not fallen after 1839.

8.For the geography of Indiana counties see Pence and Armstrong, Indiana Boundaries, 1933. I have also relied on the maps in Esarey, A History of Indiana, 1918. 
9. The 29 percent figure is taken from the enumeration of "polls" in the Indiana Auditor's Report for 1834.

10.Larson, Internal Improvements, 2001, p. 207. See Fatout, Indiana Canals, 1972, for a description of events leading up to the grant for the Wabash \& Erie.

11.We do not have the numbers for 1839. The Auditor reported in 1841 that per acre values in Indiana were $\$ 7.30$ in $1838, \$ 8.80$ in $1839,7.05$ in 1840 , and $\$ 6.18$ in 1841 . These numbers are not exactly the same as the actual numbers presented in earlier Auditor's Reports, but they are consistent. The Auditor felt that 1839 was the peak year for land values in Indiana.

12.More land was sold in 1836 than in any other year in the nation's history. The reasons for the land boom have never been satisfactorily explained, booms rarely are completely understandable, and there has been considerable disagreement about the causes of the Panic of 1837 that checked the land boom. Peter Temin's Jacksonian Economy transformed the history of the early 1830s by pointing out that the inflation up to 1836, and undoubtedly part of the land boom, was not caused by the "Bank War" -- the battle between President Andrew Jackson and Nicholas Biddle, president of the Second Bank of the United State, over the course of banking policy in the country - but by international specie flows. Temin's explanation of the Panic of 1837 and the Crisis of 1839 have recently been questioned by Rousseau (JEH, 2001/2) and Wallis (NBER, 2001).

13. Noble would head the Internal Improvement Board when his second term as Governor ended in 1837. The Indiana Democrat, July 19, 1837 chastised Noble and governor elect Wallace: "When the subject of internal improvements was first agitated by Ex. Governor Ray; Gov. Noble and Wallace were opposed to it. Ray was regarded as a visionary schemer, the advantages of internal improvements were underrated; and the resources of the state were not duly estimated. It was good policy, no doubt then, on the part of Noble and Wallace, to oppose internal improvements, and the Gov. then rode the anti internal improvements hob by, with whip and spur, with as much speed as he now rides the internal improvement hobby."

14.Riker and Thornbrough, Noble Papers, p. 204-5.

\section{As quoted in Carmony, p. 191.}

16.Robertson and Riker, ed. The John Tipton Papers, III, p. 127. "Assemblymen wrestled with a multitude of proposals, making the usual vote-swapping bargains with each other, but they could not agree on the details of a general system satisfactory to all the clamorous sections of the state." Fatout, p. 67.

17. I refer to Esarey, Fatout, Carmony, Duden, Miller, Riker and Thornbrough, Cottman, Benton, Chambers, and Comstock. The closest to explicit recognition of the link between the tax bill and the internal improvement bill comes in Riker and Thornbrough, p. 316 and Carmony, p. 158 (discussed below in note 22).

The irresistible tendency is to suggest that Indiana made no provision for taxation at all 
when it started the Mammoth system. For example, "Numerous politicians and voters alike persuaded themselves that a system of internal improvements could be financed through long term loans paid for largely, if not entirely, by revenue generated by the resulting, canals, railroads, and turnpikes." Carmony, p. 185.

Or "The plan that emerged was a splendid free gift offered to the public with emphatic assurances that it would not cost anybody one cent of additional taxes" Fatout, p. 73.

Carmony and Fatout accurately reflect the general feeling that the Mammoth system would not result in higher taxes, while ignoring the explicit arrangement that legislators had made about the distribution of taxes should higher taxes be necessary. As soon as 1837 it was necessary to raise the tax rate from .5 mill to 1 mill. Tax rates would eventually rise to 4 mills in 1841 in an attempt to stave off default.

18.Esarey's essay on Internal Improvements in Early Indiana concludes with a sweeping indictment of Indiana politics in 1835 and 1836, taken from the words of Indiana politicians at the constitutional convention in $1850(?)$.

19.Indiana Laws, February 10, 1831, Chapter LXXXI, General Assembly, $15^{\text {th }}$ session, pp. 42627.

20.See, for example, the letter from Richard Thompson to Governor Noble in Riker and Thornbrough, Noble Papers, 1958, pp. 370-73.

21.Riker and Thornbrough, Noble Papers, p. 315.

22. Laws of Indiana, Chapter XI, $19^{\text {th }}$ session, p. 14.

23.As quoted in Carmony, p. 158; also referenced in Riker and Thornbrough, p. 316. The microfilm records of the Indiana Democrat that I have so far been able to obtain, unfortunately do not include the February 27, 1835 issue. As far as I can determine, this lead was never followed up by the Indiana historians.

24.Riker and Thornbrough, Noble Papers, p. 407.

25.Fifteen new counties were created in 1835, and these are not included in the comparison. Neither are the seven counties created between 1836 and 1844. Of the existing counties in existence in 1834, fifteen reported incomplete information in 1834 or 1835.

26.It seems natural to include the value of own lots in the value of land, but a problem arises when we compare per acre valuations across counties. In most Indiana counties, the value of town lots per acre of land fell in the late 1830 s as the amount of land subject to taxation rose. This has nothing to do with the actual value of the town lots, it is a result driven by acreage. Since the results in the paper would only be stronger if town lots were included, I have chosen to leave them out.

27.Riker and Thornbrough, Noble Papers, p. 407. 
28. There are no sampling issues in these regressions, the entire universe of Indiana counties is represented (barring missing information on a county), so the standard errors provide information more on the fit of the variables rather than their statistical significance.

29.See Fatout, pp. 96-106. The default crisis is considered in much greater detail, including the situation in Indiana in Wallis, Grinath, and Sylla, "Debt, Default, and Revenue Structure" and the particular importance of the Morris defaults in 1839 for Indiana and the nation as a whole in Wallis, "What Caused the Crisis of 1839?"

30.This is the mean increase in land values per acre across counties, that is, it is the average of the county values. The numbers in Table 1 show that the average acre of land rose from $\$ 5.41$ per acre in 1835 to $\$ 9.87$ in 1837 . These numbers are the average value for all acres, that is, total value of land in the state divided by total acreage. Because land values are not distributed equally over all counties, the two "averages" are slightly different.

31. Ultimately the Wabash and Erie, and the Whitewater canal were completed, but not until later in the 1840s. In effect, even the estimates comparing 1837 and 1842 underestimate the effect of canals, since people knew that there were plans in the works to complete those two canals. The lower portion of the Whitewater canal had been completed in 1839. Later we will see that land values along the Whitewater rose between 1837 and 1842.

32.If counties with higher taxes under the ad valorem system are compared to counties with lower taxes, i.e. using a break point of one, the difference estimate is small and statistically insignificant. There are a number of counties clustered around a ratio of one. A regression of the change in land values between 1835 and 1837 on the tax ratio is provided in table 4 . A rise in the tax ratio of .01 increases land values by about $\$ .02$ an acre.

33.For a brief history of the Whitewater Canal see Miller, 1907.

34.Indiana had raised the property tax rate to 4 mills in 1841, in an attempt to stave off default. 


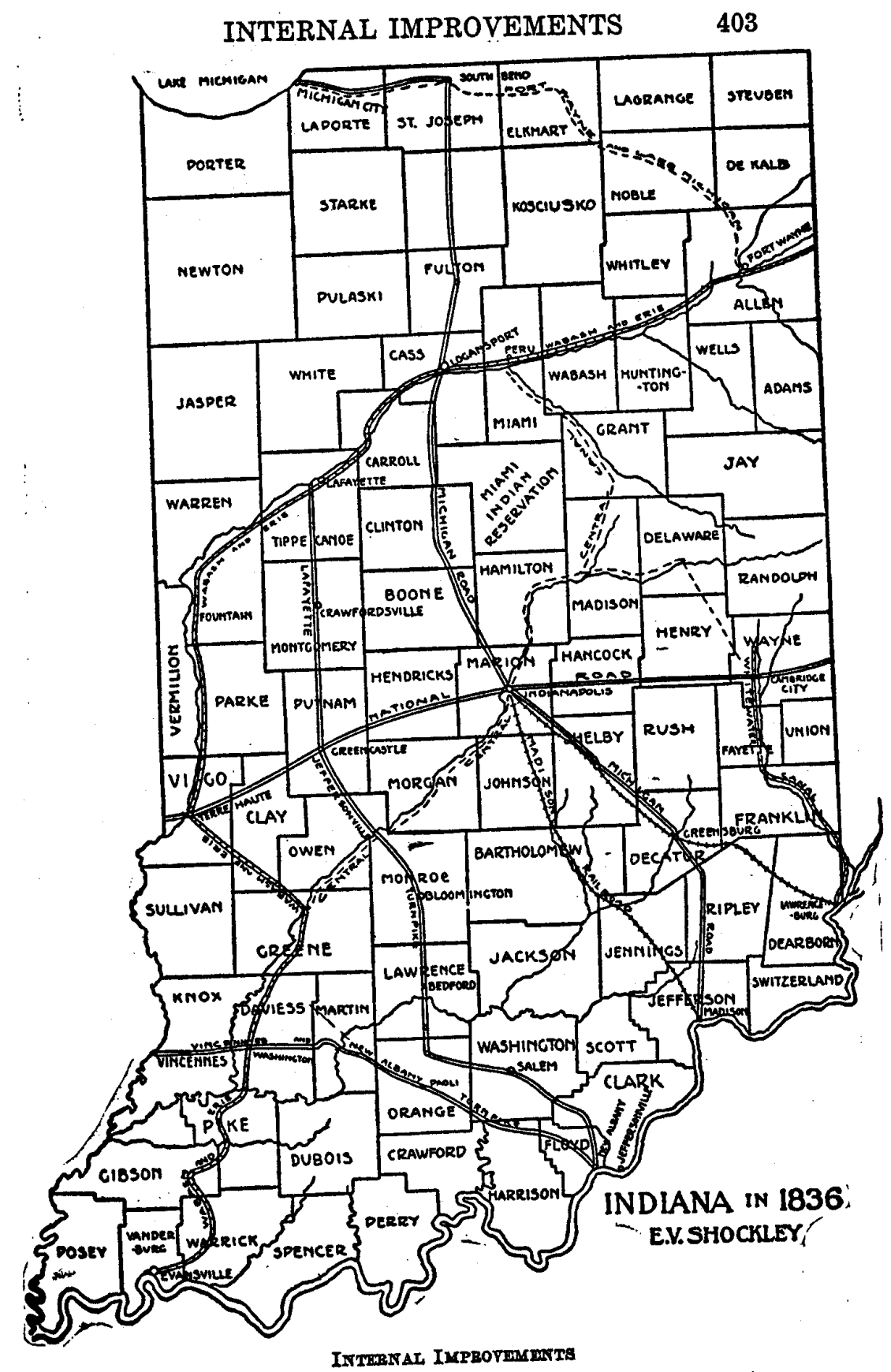




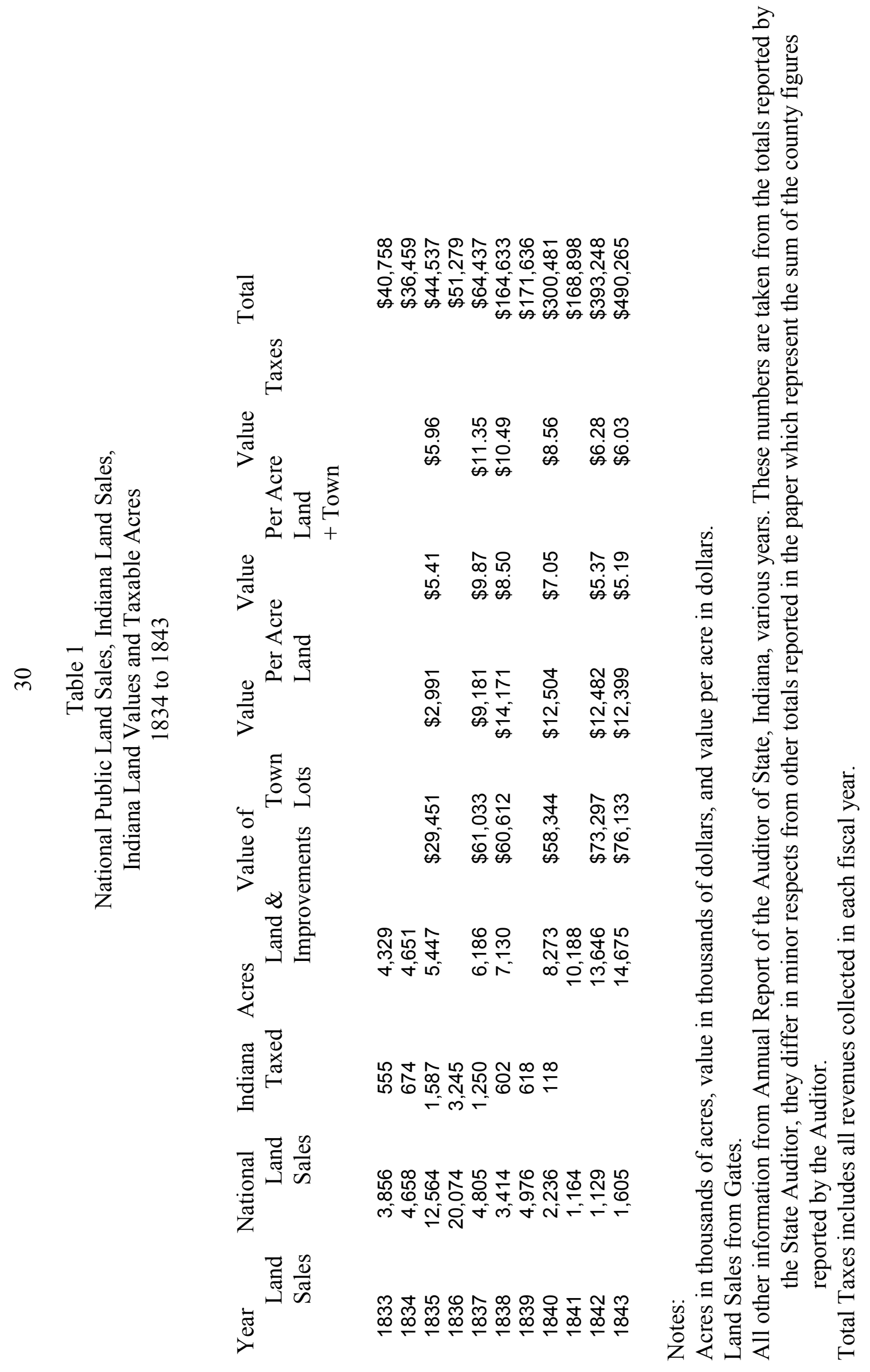


Table 3

Difference in Difference Estimates

Change in Average Land Value Per Acre

Indiana Counties

All Counties

$\$ 3.90$

$-\$ 4.21$

Internal Improvement Counties

$\$ 4.55$

$-\$ 5.49$

Non-Internal Improvement

$\$ 2.74$

$-\$ 2.80$

Counties

$\$ 1.81$

$-\$ 2.69$

Difference

60

75

N

$\$ 8.29$

$-\$ 9.06$

Terminus Counties

$\$ 2.93$

$-\$ 3.11$

Non-Terminus Counties

$\$ 5.36$

$-\$ 5.95$

$\mathrm{N}$

60

75

High Tax Ratio Counties

Ad valorem > 1.2 Per Acre

$\$ 4.91$

$-\$ 5.38$

Low Tax Counties

Ad Valorem < .8 Per Acre

$\$ 2.99$

$-\$ 2.14$

Difference

$\$ 1.92$

$-\$ 3.24$

$\mathrm{N}$

52

51

Notes:

Average land values per acre are calculated for land and improvements. They do no include town lots or personal property.

The number of observations in each cell varies. All differences are statistically significant at the 10 percent level or higher. 
Table 2

Regression of the Ratio of Ad Valorem taxes levied in 1835

to the Per Acre taxes levied in 1834

on County Characteristics

(Standard errors)

\begin{tabular}{l|rrrr|}
$\begin{array}{l}\text { Internal } \\
\text { Improvement }\end{array}$ & \multicolumn{1}{c}{.33} & --- & --- & --- \\
Terminus & $(.15)$ & & & \\
& --- & .73 & --- & --- \\
Town Lands & & $(.18)$ & & \\
as Share of & --- & --- & 2.45 & \\
Total Value & & & $(.45)$ & --- \\
Latitude & & & & \\
& --- & --- & --- & .20 \\
Intercept & & & & $(.10)$ \\
$\mathrm{N}$ & .78 & .86 & .71 & -7.08 \\
$\mathrm{R} 2$ & $(.12)$ & $(.07)$ & $(.08)$ & $(3.9)$ \\
& 53 & 53 & 53 & 53 \\
& 0.09 & 0.24 & 0.36 & .08
\end{tabular}

Notes: Dependent variable in all regressions "Ratio of Taxes in 1835/1834," a continuous variable measuring the ratio of ad valorem taxes levied in 1835 to the per acre taxes levied in 1834.

All observations are county means or dummy variables.

"Internal Improvement" is a dummy variable equal to 1 if a county has a canal, railroad, or turnpike.

"Terminus" is a dummy variable equal to 1 if a county contains an intersection of a canal, railroad, turnpike, and/or river.

"Town Lands" is a continuous variable measuring the share of town lands in total value of all lands in 1835 .

"Latitude" is the latitude of the center point of each county. 
Table 5

Variable Means
Variable

Total acreage taxed

Total acreage taxed

Total acreage taxed

Total acreage taxed

Value of Land \& Improvements

Value of Land \& Improvements

Value of Land \& Improvements

Value of Land Per Acre

Value of Land Per Acre

Value of Land Per Acre

Change in value per acre

Change in value per acre

Number of polls

Number of polls

Number of polls

Latitude

Dummy Variables

Terminus

Turnpike

Wabash and Erie Canal

Whitewater Canal

Central Canal

Railroad

Ohio River
Standard

Year N Mean Deviation

$\begin{array}{rrrr}1834 & 63 & 73,873 & 50,708 \\ 1835 & 63 & 86,663 & 97,443 \\ 1837 & 79 & 77,033 & 62,464 \\ 1842 & 86 & 158,679 & 76,444 \\ & & & \\ 1835 & 62 & \$ 479,086 & \$ 420,870 \\ 1837 & 79 & \$ 772,601 & \$ 756,841 \\ 1842 & 84 & \$ 867,064 & \$ 615,253\end{array}$

$1835 \quad 62$

$\$ 5.82$

$\$ 2.23$

$1837 \quad 79$

$\$ 9.37$

$\$ 5.17$

$\$ 4.91$

1842

84

$\$ 3.90$

$-\$ 4.21$

$\$ 4.46$

1837 to 1842

1835

60

1,071

$\$ 4.28$

1837

1842

82

1,016

550

626

690

92

39.84

1.07

92

92

92

92

$\begin{array}{ll}0.15 & 0.36 \\ 0.39 & 0.49 \\ 0.22 & 0.41 \\ 0.04 & 0.21\end{array}$

0.36

0.41

0.21 
Table 4

Regressions of the Change in Value Per Acre

1835 to 1837 and 1837 to 1842

on County Characteristics

(Standard errors)

1835 to 1837

1837 to 1842

\begin{tabular}{|c|c|c|c|c|c|c|}
\hline $\begin{array}{l}\text { Internal } \\
\text { Improvement }\end{array}$ & $\begin{array}{c}1.81 \\
(1.17)\end{array}$ & --- & --- & $\begin{array}{r}-2.69 \\
(.93)\end{array}$ & --- & --- \\
\hline Terminus & --- & $\begin{array}{c}5.35 \\
(1.33)\end{array}$ & --- & --- & $\begin{array}{l}-5.95 \\
(1.07)\end{array}$ & --- \\
\hline $\begin{array}{l}\text { Ratio of } \\
\text { Taxes in } \\
1835 / 1834\end{array}$ & --- & --- & $\begin{array}{l}2.02 \\
(.94)\end{array}$ & --- & --- & $\begin{array}{r}-2.77 \\
(.80)\end{array}$ \\
\hline $\begin{array}{l}\mathrm{N} \\
\mathrm{R} 2\end{array}$ & $\begin{array}{r}60 \\
0.04\end{array}$ & $\begin{array}{r}60 \\
0.22\end{array}$ & $\begin{array}{r}52 \\
0.08\end{array}$ & $\begin{array}{r}75 \\
0.09\end{array}$ & $\begin{array}{r}75 \\
0.29\end{array}$ & $\begin{array}{r}51 \\
0.19\end{array}$ \\
\hline $\begin{array}{l}\text { Internal } \\
\text { Improvement }\end{array}$ & $\begin{array}{c}0.34 \\
(1.14)\end{array}$ & --- & & $\begin{array}{r}-1.06 \\
(.89)\end{array}$ & -- & \\
\hline Terminus & $\begin{array}{c}5.21 \\
(1.43)\end{array}$ & $\begin{array}{c}3.79 \\
(1.69)\end{array}$ & & $\begin{array}{l}-5.44 \\
(1.15)\end{array}$ & $\begin{array}{l}-5.33 \\
(1.24)\end{array}$ & \\
\hline $\begin{array}{l}\text { Wabash \& } \\
\text { Erie }\end{array}$ & --- & $\begin{array}{c}0.17 \\
(1.31)\end{array}$ & & --- & $\begin{array}{l}-0.32 \\
(1.01)\end{array}$ & \\
\hline $\begin{array}{l}\text { Ohio } \\
\text { River }\end{array}$ & --- & $\begin{array}{l}-0.04 \\
(1.72)\end{array}$ & & --- & $\begin{array}{l}-0.12 \\
(1.13)\end{array}$ & \\
\hline $\begin{array}{r}\text { Central } \\
\text { Canal }\end{array}$ & --- & $\begin{array}{c}1.26 \\
(1.33)\end{array}$ & & --- & $\begin{array}{l}-2.53 \\
(1.11)\end{array}$ & \\
\hline Turnpike & --- & $\begin{array}{l}-0.12 \\
(1.14)\end{array}$ & & --- & $\begin{array}{l}0.97 \\
(.81)\end{array}$ & \\
\hline $\begin{array}{l}\text { WhiteWater } \\
\text { Canal }\end{array}$ & --- & $\begin{array}{l}-0.12 \\
(2.23)\end{array}$ & & --- & $\begin{array}{c}3.53 \\
(1.80)\end{array}$ & \\
\hline $\begin{array}{l}\text { Fort Wayne } \\
\text { \& Mlchigan }\end{array}$ & --- & $\begin{array}{c}6.51 \\
(2.20)\end{array}$ & & --- & $\begin{array}{l}-6.35 \\
(1.80)\end{array}$ & \\
\hline Railroad & --- & $\begin{array}{c}2.55 \\
(1.61)\end{array}$ & & --- & $\begin{array}{l}-1.34 \\
(1.29)\end{array}$ & \\
\hline $\mathrm{N}$ & 60 & 60 & & 75 & 75 & \\
\hline R2 & 0.22 & 0.36 & & 0.3 & 0.48 & \\
\hline
\end{tabular}


Table 4 (cont.)

Notes: Dependent variable in all regressions is the change in the per acre value of land and improvements. All observations are county means or dummy variables.

Intercept not reported because of space limitations.

"Internal Improvement" is a dummy variable equal to 1 if a county has a canal, railroad, or turnpike.

"Terminus" is a dummy variable equal to 1 if a county contains an intersection of a canal, railroad, turnpike, and/or river.

"Ratio of Taxes in 1835/1834 is a continuous variable measuring the ratio of ad valorem taxes levied in 1835 to the per acre taxes levied in 1834 .

The remaining variables are dummies for the counties that border on or contain the Wabash and Erie Canal, the Ohio River, the Central Canal, a turnpike, the Whitewater Canal, the Fort Wayne and Michigan Canal, ora railroad. 


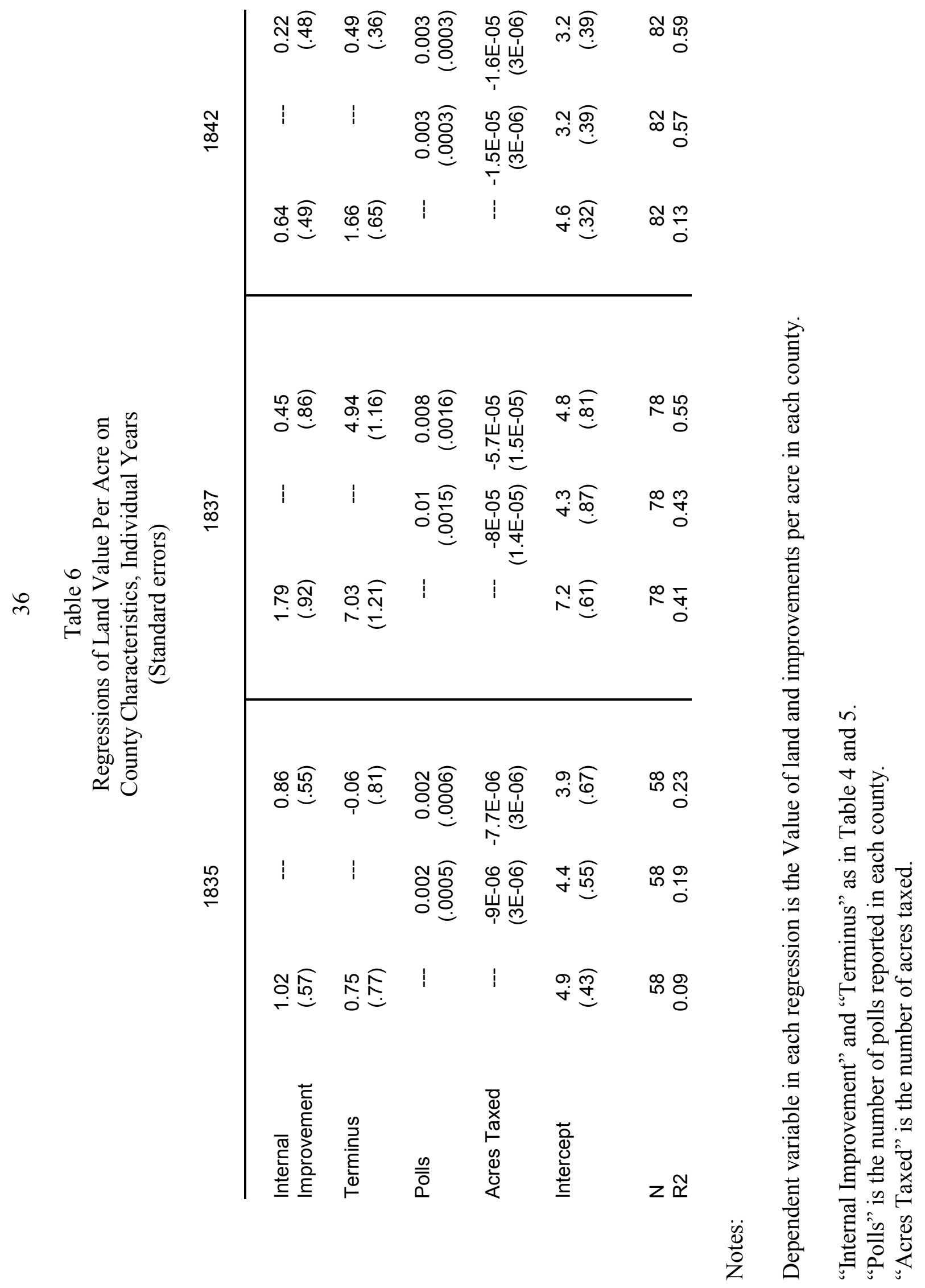


Table 7

Effect of Internal Improvements and Terminus Counties

On the Change in Land Values, 1835 to 1842

\begin{tabular}{|c|c|c|c|c|c|}
\hline \multirow[b]{2}{*}{ All Counties } & \multirow[b]{2}{*}{1835} & \multirow[b]{2}{*}{1837} & \multicolumn{3}{|c|}{ Change Between } \\
\hline & & & 1842 & 1835 to 1837 & 1837 to 1842 \\
\hline Acres Subject to Tax & $5,459,782$ & $6,085,609$ & $13,646,412$ & 625,827 & $7,560,803$ \\
\hline $\begin{array}{l}\text { Value of Land and } \\
\text { Improvements }\end{array}$ & $\$ 29,703,358$ & $\$ 61,035,465$ & $\$ 72,833,416$ & $\$ 31,332,107$ & $\$ 11,797,951$ \\
\hline Value per acre & $\$ 5.44$ & $\$ 10.03$ & $\$ 5.34$ & $\$ 4.59$ & $-\$ 4.69$ \\
\hline Int. Imp. Counties & & & & & \\
\hline Acres Subject to Tax & $3,603,544$ & $4,079,921$ & $9,348,493$ & 476,377 & $5,268,572$ \\
\hline $\begin{array}{l}\text { Value of Land and } \\
\text { Improvements }\end{array}$ & $\$ 24,829,083$ & $\$ 48,128,255$ & $\$ 56,746,994$ & $\$ 23,299,172$ & $\$ 8,618,739$ \\
\hline Value per acre & $\$ 6.89$ & $\$ 11.80$ & $\$ 6.07$ & $\$ 4.91$ & $-\$ 5.73$ \\
\hline $\begin{array}{l}\text { Change Attributed to } \\
\text { Internal Improvement } \\
\text { Effect }\end{array}$ & & & & $\$ 16,920,772$ & $-\$ 25,147,446$ \\
\hline Terminus Counties & & & & & \\
\hline Acres Subject to Tax & $1,172,217$ & $1,327,024$ & $2,643,518$ & 154,807 & $1,316,494$ \\
\hline $\begin{array}{l}\text { Value of Land and } \\
\text { Improvements }\end{array}$ & $\$ 8,944,184$ & $\$ 19,127,720$ & $\$ 18,551,453$ & $\$ 10,183,536$ & $-\$ 576,267$ \\
\hline Value per acre & $\$ 7.63$ & $\$ 14.41$ & $\$ 7.02$ & $\$ 6.78$ & $-\$ 7.40$ \\
\hline $\begin{array}{l}\text { Change Attributed to } \\
\text { Terminus Effect }\end{array}$ & & & & $\$ 21,914,764$ & $-\$ 23,950,273$ \\
\hline
\end{tabular}

Notes:

The change in the value of land and improvements attributed to the Internal Improvement effect and the Terminus effect is calculated by taking the difference in difference estimate of the effect of Internal Improvement on land values or of the Terminus effect on land values, multiplied by either acreage in Internal Improvement counties or Terminus counties in 1842. 
References

Benton, Elbert Jay. (1907), "Internal Improvements in Indiana. No III - The Wabash and Erie Canal." Indiana Magazine of History, vol. III, March, pp. 101-107.

Carmony, Donald F. (1998), Indiana 1816-1850: The Pioneer Era. Indianapolis: Indiana Historical Bureau and Indiana Historical Society.

Chambers, Smiley N. (1907), "Internal Improvements in Indiana. No II - The National Road." Indiana Magazine of History, vol. III, pp. 58-73.

Coffman, Chad and Gregson, Mary Eschelbach. (1998), "Railroad Development and Land Values."Journal of Real Estate Finance and Economics, Vol. 16, No. 2, March, 191-204.

Comstock, Howard Payne, "History of Canals in Indiana." (1911), Indiana Magazine of History, vol. VII, pp. 1-15.

Cottman, George S. “The Internal Improvement System of Indiana.” (1907), Indiana Magazine of History, vol. III, March, pp. 117-124.

Cottman, George S. “The Central Canal.” (1907), Indiana Magazine of History, vol. III, March, 1907, pp. 115-6.

Craig, Lee, Palmquist, and Thomas Weiss, (1998), "Transportation Improvements and Land Values in the Antebellum United States" Journal of Real Estate Finance and Economics, Vol. 16, No. 2 March, 173-190.

Duden, Margaret, “Internal Improvements in Indiana, 1818-1846.” Indiana Magazine of History, vol. V, 1909, pp. 160-170.

English, William B. (1996), "Understanding the Costs of Sovereign Default: American State Debts in the 1840's." American Economic Review 86 (March 1996): 259-75.

Esarey, Logan. (1918), A History of Indiana: From its Exploration to 1860. Indianapolis: B. F. Bowen and Company.

-----. (1912), “State Banking in Indiana.” Indiana University Studies, April.

-----. (1912), Internal Improvements in Early Indiana, Indiana Historical Society Publications.

Fatout, Paul. (1972), Indiana Canals. West Lafayette, Indiana: Purdue University Studies.

Fogel, Robert William. (1964), Railroads and American Economic Growth. Baltimore: Johns Hopkins University Press. 
Gates, Paul Wallace. (1968), History of Public Land Law Development. Washington, D.C.: GPO.

Goodrich, Carter. (1960), Government Promotion of American Canals and Railroads. New York: Columbia University Press.

-----. (1948), “National Planning of Internal Improvements.” Political Science Quarterly 63, pp. 16-44.

Larson, John Lauritz. (2001), Internal Improvement: National Public Works and the Promise of Popular Government in the United States. Chapel Hill: University of North Carolina Press.

-----. (1987), “'Bind the Republic Together': The National Union and the Struggle for a System of Internal Improvements.” Journal of American History 74, pp. 363-87.

McGrane, Reginald C. (1935), Foreign Bondholders and American State Debts. New York: Macmillan Company, 1935.

Miller, James M. (1907), “The Whitewater Canal.” Indiana Magazine of History, vol. III, March, pp. 108-115.

Miller, Nathan. (1962), The Enterprise of A Free People: Aspects of Economic Development in New York State during the Canal Period, 1792-1838. Ithaca: Cornell University Press.

Pence, George and Nellie C. Armstrong. (1933). Indiana Boundaries: Territory, State, and County. Indiana Historical Collections, Volume XIX, Indianapolis: Indiana Historical Bureau.

Ratchford, B. U. (1941), American State Debts. Durham: Duke University Press.

Riker, Dorothy. Ed. (1963), Governor David Wallace: Messages and Papers: 1837-1840. Indiana Historical Collections, Volume XLIII. Indianapolis: Indiana Historical Bureau.

Riker, Dorothy and Gayle Thornbrough, Eds.(1958), Governor Noah Noble: Messages and Papers, 1831-1837. Indiana Historical Collections, Volume XXXIII, Indianapolis: Indiana Historical Bureau.

Robertson, Nellie Armstrong and Dorothy Riker, Eds. (1942), The John Tipton Papers, Vol. III, 18341839. Indianpolis: Indiana Historical Bureau.

Rousseau, Peter L. (2000), “Jacksonian Monetary Policy, Specie Flows, and the Panic of 1837.” NBER Working Paper 7528, February. Forthcoming Journal of Economic History.

Scheiber, Harry N. (1969), Ohio Canal Era: A Case Study of Government and the Economy, 1820-1861. Athens, Ohio: The Ohio State University Press.

Sylla, Richard and John Joseph Wallis. (1998) “The Anatomy of a Sovereign Debt Crisis.” Japan and the World Economy. 
Temin, Peter. (1969), The Jacksonian Economy. New York: W. W. Norton and Company, 1969.

Wallis, John Joseph, Richard E. Sylla, and John B. Legler. (1994), "The Relationship between Taxation and Regulation of Banks in early Nineteenth Century America" in C. Goldin and G. Libecap, eds. The Regulated Economy: A Historical Approach to Political Economy Chicago: University of Chicago Press, pp. 121-44.

Wallis, John Joseph, Arthur Grinath, and Richard Sylla, (2001), "Debt, Default, and Revenue Structure." NBER Working Paper, and mimeo.

Wallis, John Joseph. (2001), “What Caused the Crisis of 1839?” NBER Working Paper, 2001. 
Appendix Table A1

Ratio of Taxes Paid under Per Acre and Ad Valorem taxes

\begin{tabular}{|c|c|c|c|c|}
\hline \multirow[t]{2}{*}{ County } & Ratio & \multicolumn{2}{|c|}{ Percent } & \multirow[t]{2}{*}{ Terminus } \\
\hline & & Town Lots & County & \\
\hline Martin & 0.42 & 0.10 & & 0 \\
\hline Scott & 0.49 & 0.08 & & 0 \\
\hline Pike & 0.54 & 0.06 & & 0 \\
\hline Daviess & 0.58 & 0.12 & & 1 \\
\hline Johnson & 0.58 & 0.04 & & 0 \\
\hline Bartholomew & 0.60 & 0.00 & & 0 \\
\hline Jennings & 0.61 & 0.09 & & 0 \\
\hline Harrison & 0.61 & 0.07 & & 0 \\
\hline Sullivan & 0.62 & 0.07 & & 0 \\
\hline Gibson & 0.63 & 0.10 & & 0 \\
\hline Randolph & 0.65 & 0.03 & & 0 \\
\hline Lawrence & 0.67 & 0.06 & & 0 \\
\hline Orange & 0.68 & 0.12 & & 0 \\
\hline Fountain & 0.68 & 0.04 & & 0 \\
\hline Rush & 0.69 & 0.03 & & 0 \\
\hline Owen & 0.69 & 0.07 & & 0 \\
\hline Jackson & 0.70 & 0.06 & & 0 \\
\hline Greene & 0.70 & 0.11 & & 0 \\
\hline Ripley & 0.73 & 0.07 & & 0 \\
\hline Knox & 0.73 & 0.37 & & 0 \\
\hline Hendricks & 0.75 & 0.05 & & 0 \\
\hline Clarke & 0.75 & 0.13 & & 0 \\
\hline Morgan & 0.75 & 0.06 & & 0 \\
\hline Warrick & 0.76 & 0.11 & & 0 \\
\hline Perry & 0.80 & 0.09 & & 0 \\
\hline Hamilton & 0.83 & 0.06 & & 0 \\
\hline Washington & 0.83 & 0.14 & & 0 \\
\hline Parke & 0.87 & 0.07 & & 0 \\
\hline Monroe & 0.88 & 0.11 & & 0 \\
\hline Marion & 0.88 & 0.35 & & 1 \\
\hline Shelby & 0.88 & 0.04 & & 0 \\
\hline Switzerland & 0.91 & 0.10 & & 0 \\
\hline Boone & 0.92 & 0.07 & & 0 \\
\hline Carroll & 0.93 & 0.08 & & 0 \\
\hline Vermilion & 0.96 & 0.12 & & 0 \\
\hline Clinton & 0.97 & 0.06 & & 0 \\
\hline Putnam & 0.98 & 0.06 & & 1 \\
\hline
\end{tabular}




$\begin{array}{llll}\text { Vigo } & 0.99 & 0.26 & 1 \\ \text { Tippecanoe } & 1.10 & 0.18 & 1 \\ \text { Clay } & 1.12 & 0.09 & 0 \\ \text { Union } & 1.12 & 0.02 & 0 \\ \text { Madison } & 1.15 & 0.04 & 0 \\ \text { Henry } & 1.18 & 0.05 & 0 \\ \text { Hancock } & 1.20 & 0.10 & 0 \\ \text { Warren } & 1.21 & 0.03 & 0 \\ \text { Fayette } & 1.22 & 0.05 & 0 \\ \text { Delaware } & 1.23 & 0.06 & 0 \\ \text { Wayne } & 1.43 & 0.13 & 1 \\ \text { Dearborn } & 1.54 & 0.14 & 1 \\ \text { St. Joseph } & 1.62 & 0.08 & 0 \\ \text { Grant } & 1.67 & 0.07 & 0 \\ \text { Franklin } & 2.01 & 0.04 & 1 \\ \text { Cass } & 2.14 & 0.80 & 1 \\ \text { Jefferson } & 4.12 & 0.63 & \end{array}$

Notes:

Ratio $1835 / 34$ is the ratio of taxes paid under the proposed ad valorem tax in 1835 to taxes paid by the county in 1834 under the per acre land tax. Both figures are taken from the Report of the State Auditor for 1834 and 1835.

The table only includes counties with complete information in the 1834 and 1835 reports.

Town Lots is the share of all land value reported as town lots in 1835.

Terminus equals 1 if the county contains the junction of two transportation lines. 
Appendix Table A2

Per Acre Land Values and the Change in Land Values

1835, 1837, and 1842

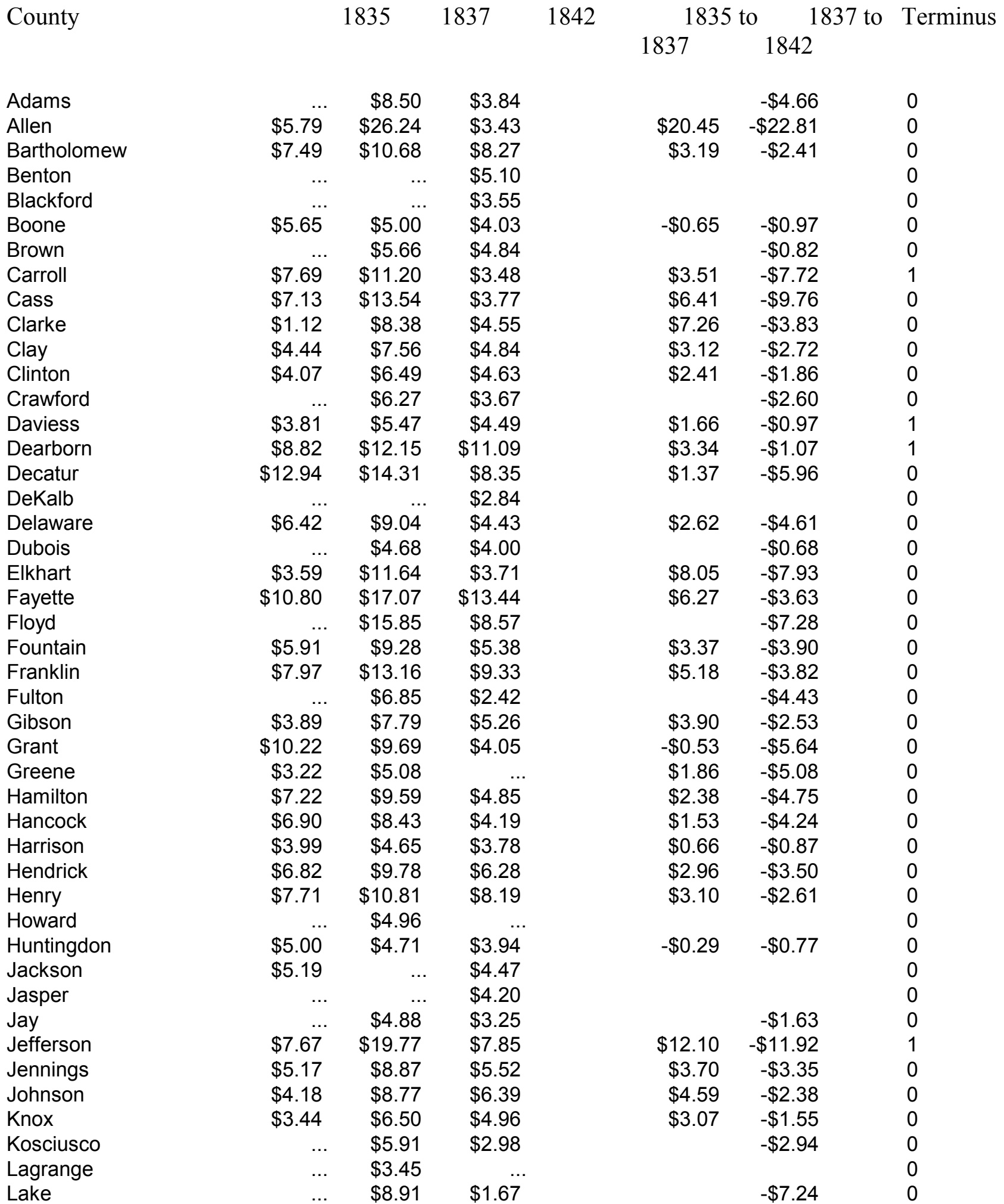




\begin{tabular}{|c|c|c|c|c|c|}
\hline Laporte & $\$ 4.84$ & $\$ 14.08$ & $\$ 4.24$ & $\$ 9.24$ & $-\$ 9.84$ \\
\hline Lawrence & $\$ 4.49$ & $\$ 7.78$ & $\$ 5.98$ & $\$ 3.29$ & $-\$ 1.81$ \\
\hline Madison & $\$ 11.52$ & $\$ 9.30$ & $\$ 4.32$ & $-\$ 2.22$ & $-\$ 4.99$ \\
\hline Marion & $\$ 6.24$ & $\$ 33.47$ & $\$ 9.79$ & $\$ 27.23$ & $-\$ 23.68$ \\
\hline Marshall & & $\$ 7.82$ & $\$ 2.04$ & & $-\$ 5.78$ \\
\hline Martin & $\$ 3.05$ & $\$ 3.41$ & $\$ 5.12$ & $\$ 0.36$ & $\$ 1.71$ \\
\hline Miami & & $\$ 18.15$ & $\$ 3.80$ & & $-\$ 14.36$ \\
\hline Monroe & $\$ 4.95$ & $\$ 8.43$ & $\$ 5.96$ & $\$ 3.47$ & $-\$ 2.47$ \\
\hline Montgomery & $\$ 4.43$ & $\$ 9.50$ & $\$ 6.79$ & $\$ 5.07$ & $-\$ 2.71$ \\
\hline Morgan & $\$ 4.80$ & $\$ 9.16$ & $\$ 5.71$ & $\$ 4.36$ & $-\$ 3.46$ \\
\hline Newton & $\ldots$ & $\ldots$ & & & \\
\hline Noble & $\ldots$ & $\ldots$ & $\$ 2.15$ & & \\
\hline Ohio & & & & & \\
\hline Orange & $\$ 4.13$ & $\$ 5.87$ & $\$ 4.58$ & $\$ 1.74$ & $-\$ 1.29$ \\
\hline Owen & $\$ 4.01$ & $\$ 6.31$ & $\$ 4.67$ & $\$ 2.29$ & $-\$ 1.64$ \\
\hline Parke & $\$ 5.99$ & $\$ 8.79$ & $\$ 5.92$ & $\$ 2.80$ & $-\$ 2.87$ \\
\hline Perry & $\$ 6.55$ & $\$ 9.81$ & $\$ 5.69$ & $\$ 3.25$ & $-\$ 4.11$ \\
\hline Pike & $\$ 3.57$ & $\$ 6.56$ & $\$ 4.79$ & $\$ 2.99$ & $-\$ 1.78$ \\
\hline Porter & $\ldots$ & $\$ 8.00$ & $\$ 2.60$ & & $-\$ 5.40$ \\
\hline Posey & $\ldots$ & $\$ 7.70$ & $\$ 5.05$ & & $-\$ 2.65$ \\
\hline Pulaski & & & & & \\
\hline Putnam & $\$ 6.24$ & $\$ 9.20$ & $\$ 5.92$ & $\$ 2.96$ & $-\$ 3.28$ \\
\hline Randolph & $\$ 4.73$ & $\$ 7.95$ & $\$ 3.82$ & $\$ 3.22$ & $-\$ 4.13$ \\
\hline Ripley & $\$ 4.24$ & $\$ 6.60$ & $\$ 3.91$ & $\$ 2.36$ & $-\$ 2.69$ \\
\hline Rush & $\$ 5.43$ & $\$ 12.01$ & $\$ 9.60$ & $\$ 6.58$ & $-\$ 2.41$ \\
\hline St. Joseph & $\$ 4.54$ & $\$ 9.17$ & $\$ 3.67$ & $\$ 4.63$ & $-\$ 5.50$ \\
\hline Scott & $\$ 2.64$ & $\$ 3.76$ & $\$ 4.39$ & $\$ 1.11$ & $\$ 0.63$ \\
\hline Shelby & $\$ 6.91$ & $\$ 8.83$ & $\$ 5.89$ & $\$ 1.92$ & $-\$ 2.94$ \\
\hline Spencer & $\ldots$ & $\$ 6.47$ & $\$ 4.61$ & $\$ 6.47$ & $-\$ 1.86$ \\
\hline Starke & $\ldots$ & $\ldots$ & & & \\
\hline Stueben & $\ldots$ & $\ldots$ & $\$ 2.14$ & & \\
\hline Sullivan & $\$ 3.97$ & $\$ 5.55$ & $\$ 3.81$ & $\$ 1.59$ & $-\$ 1.74$ \\
\hline Switzerland & $\$ 8.04$ & $\$ 9.93$ & $\$ 6.09$ & $\$ 1.89$ & $-\$ 3.84$ \\
\hline Tippecanoe & $\$ 6.17$ & $\$ 12.47$ & $\$ 6.36$ & $\$ 6.30$ & $-\$ 6.11$ \\
\hline Tipton & & $\ldots$ & $\ldots$ & & \\
\hline Union & $\$ 9.61$ & $\$ 15.11$ & $\$ 8.42$ & $\$ 5.50$ & $-\$ 6.70$ \\
\hline Vanderburg & & $\$ 18.09$ & $\$ 5.57$ & & $-\$ 12.52$ \\
\hline Vermilion & $\$ 5.89$ & $\$ 7.63$ & $\$ 5.12$ & $\$ 1.74$ & $-\$ 2.51$ \\
\hline Vigo & $\$ 7.06$ & $\$ 9.97$ & $\$ 7.63$ & $\$ 2.91$ & $-\$ 2.34$ \\
\hline Wabash & $\$ 4.33$ & $\$ 4.13$ & $\$ 4.30$ & $-\$ 0.19$ & $\$ 0.16$ \\
\hline Warren & $\$ 5.07$ & $\$ 9.31$ & $\$ 4.14$ & $\$ 4.24$ & $-\$ 5.17$ \\
\hline Warrick & $\$ 4.83$ & $\$ 7.61$ & $\$ 4.34$ & $\$ 2.78$ & $-\$ 3.27$ \\
\hline Washington & $\$ 5.03$ & $\$ 7.51$ & $\$ 5.76$ & $\$ 2.48$ & $-\$ 1.75$ \\
\hline Wayne & $\$ 9.01$ & $\$ 13.82$ & $\$ 11.15$ & $\$ 4.81$ & $-\$ 2.66$ \\
\hline Wells & & $\$ 4.33$ & $\$ 4.02$ & & $-\$ 0.30$ \\
\hline White & $\$ 4.45$ & $\$ 5.08$ & $\$ 3.34$ & $\$ 0.63$ & $-\$ 1.75$ \\
\hline Whitely & $\ldots$ & $\ldots$ & $\$ 2.85$ & & $\$ 2.85$ \\
\hline
\end{tabular}

